REGARDS

SUR L'ECONOMIE ALLEMANDE

BULLETIN ECONOMIQUE DU CRAC

\section{Regards sur l'économie allemande}

Bulletin économique du CIRAC

$68 \mid 2004$

Varia

\title{
Economie de réseaux
}

OBERENDER Peter (ed.), Wettbewerb in der Versorgungswirtschaft

\section{OpenEdition}

\section{Journals}

Édition électronique

URL : http://journals.openedition.org/rea/3640

DOI : $10.4000 /$ rea. 3640

ISBN : 978-2-8218-0832-4

ISSN : 1965-0787

Éditeur

CIRAC

Édition imprimée

Date de publication : 1 octobre 2004

ISSN : 1156-8992

Référence électronique

"Economie de réseaux », Regards sur l'économie allemande [En ligne], 68 | octobre 2004, mis en ligne le 29 avril 2009, consulté le 22 septembre 2020. URL : http://journals.openedition.org/rea/3640 ; DOI : https://doi.org/10.4000/rea.3640

Ce document a été généré automatiquement le 22 septembre 2020

(C) CIRAC 


\section{Economie de réseaux}

OBERENDER Peter (ed.), Wettbewerb in der Versorgungswirtschaft

\section{RÉFÉRENCE}

OBERENDER Peter (ed.), Wettbewerb in der Versorgungswirtschaft, Coll. Schriften des Vereins für Socialpolitik, vol. 299, Duncker \& Humblot, Berlin, 2004, 100 p.

1 Cet ouvrage collectif dresse le bilan de cinq ans de libéralisation dans le secteur du gaz et de l'électricité outre-Rhin. S'il est dans l'ensemble régi par les lois de la concurrence, il n'en reste pas moins à régler l'épineuse question de l'accès des tiers aux réseaux... (ib) 